\title{
Regioselective Alkene Carbon-Carbon Bond Cleavage to Aldehydes and Chemoselective Alcohol Oxidation of Allylic Alcohols with Hydrogen Peroxide Catalyzed by $\left[c i s-\mathrm{Ru}(\mathrm{II})(\mathrm{dmp})_{2}\left(\mathrm{H}_{2} \mathrm{O}\right)_{2}\right]^{2+}$ (dmp=2,9-dimethylphenanthroline)
}

\author{
Vladimir Kogan, Miriam M. Quintal and Ronny Neumann* \\ Department of Organic Chemistry, Weizmann Institute of Science, Rehovot, Israel, 76100
}

Supplementary Information

Catalyst Preparation: The catalyst, $\left[\text { cis- } \mathrm{Ru}(\mathrm{II})(\mathrm{dmp})\left(\mathrm{H}_{2} \mathrm{O}\right)_{2}\right]^{2+}$, was prepared according to the procedures described in the literature (Collin, J. P.; Sauvage, J. P. Inorg. Chem. 1986, 25, 135 and Goldstein, A. S.; Beer, R. H.; Drago, R. S. J. Am. Chem. Soc. 1994, 116, 2424).

Oxidation Reactions: The typical procedure for oxidation of substrates presented was as follows: in $10 \mathrm{ml}$ volume vial, equipped with glass-covered stir-bar were dissolved $8 \mathrm{mg}(0.01 \mathrm{mmol})$ of [cis$\left.\mathrm{Ru}(\mathrm{II})(\mathrm{dmp})\left(\mathrm{H}_{2} \mathrm{O}\right)_{2}\right]^{2+}$ in $3 \mathrm{~mL}$ of acetonitrile under agitation in a ultrasound bath, and $1 \mathrm{mmol}$ of substrate and chlorobenzene $(0.1 \mathrm{mmol})$ as internal standard was added. The solution was placed in preheated, $55^{\circ} \mathrm{C}$, oil bath and stirred for half hour. Portions of $2 \mathrm{mmol} 30 \%$ aqueous $\mathrm{H}_{2} \mathrm{O}_{2}$ were added in intervals of $1 \mathrm{~h}$ combined with a monitoring of the reaction by GC (column was $5 \%$ phenyl methylsilicone $0.32 \mathrm{~mm}$ ID, $0.25-\mu \mathrm{m}$ coating, 30-m-length column (Restek 5MS). Compounds were identified by use of reference compounds and/or GC/MS measurements. For experiment using 7methyl-1,6-octadiene as substrate the by-product epoxide was identified by it MS and use of a authentic epoxide prepared by the MCPA oxidation of the substrate $m / z=140(0.9), 125(4.7)$, $111(2.8), 97(6.6), 85(9.8), 81(14.2), 71(12.3), 67(100)$ and 59(47.6).

Computational Methods: Calculations were carried out using Gaussian 03 revision B02 (Frisch, M. J.; Trucks, G. W.; Schlegel, H. B.; Scuseria, G. E.; Robb, M. A.; Cheeseman, J. R. ; Montgomery, J. A., Jr.; Vreven, T.; Kudin, K. N.; Burant, J. C.; Millam, J. M.; Iyengar, S. S.; Tomasi, J.; Barone, V.; Mennucci, B.; Cossi, M.; Scalmani, G.; Rega, N.; Petersson, G. A.; Nakatsuji, H.; Hada, M.; Ehara, M.; Toyota, K.; Fukuda, R.; Hasegawa, J.; Ishida, M.; Nakajima, T.; Honda, Y.; Kitao, O.; Nakai, H.; Klene, M.; Li, X.; Knox, J. E.; Hratchian, H. P.; Cross, J. B.; Adamo, C.; Jaramillo, J.; Gomperts, R.; Stratmann, R. E.; Yazyev, O.; Austin, A. J.; Cammi, R.; Pomelli, C.; Ochterski, J. W.; Ayala, P. Y.; Morokuma, K.; Voth, G. A.; Salvador, P.; Dannenberg, J. J.; Zakrzewski, V. G.; Dapprich, S.; Daniels, A. D.; Strain, M. C.; Farkas, O.; Malick, D. K.; Rabuck, A. D.; Raghavachari, K.; Foresman, J. B.; Ortiz, J. V.; Cui, Q.; Baboul, A. G.; Clifford, S.; Cioslowski, J.; Stefanov, B. B.; Liu, G.; Liashenko, A.; Piskorz, P.; Komaromi, I.; Martin, R. L.; Fox, D. J.; Keith, T.; Al-Laham, M. A.; Peng, C. Y.; Nanayakkara, A.; Challacombe, M.; Gill, P. M. W.; Johnson, B.; Chen, W.; Wong, M. W.; Gonzalez, C.; Pople, J. A. Gaussian 03, revision B.02; Gaussian, Inc.: Pittsburgh PA, 2003. The density functional theory (DFT) B97-1 hybrid exchange-correlation functional, Handy et al.'s reparameterization (Singleton, J. T.; Tetrahedron 2003, 59, 1837-1857.) of Becke's B97 functional, (Becke, A. D. J. Chem. Phys. 1997, 107, 8554-8560.) was used throughout (Hamprecht, F. A.; Cohen, A. J.; Tozer, D. J.; Handy, N. C. J. Chem. Phys. 1998, 109, 6264-6271.). With this functional, the basis set-RECP (relativistic effective core potential) combination SDD was used. It is the combination of the Huzinaga-Dunning double- basis set on lighter elements with the Stuttgart-Dresden basis set-RECP combination on transition metals (Dolg, M. In Modern Methods and Algorithms of Quantum Chemistry; Grotendorst, J., Ed.; John von Neumann Institute for Computing: Jülich, 2000; Vol. 1, pp 479-508.). 